\title{
Serum Chemerin Level in Breast Cancer
}

\author{
Serkan AKIN', Safak AKIN², Emre GEDIK ${ }^{3}$, Elif HAZNEDAROGLU³, \\ Ayse L. DOGAN ${ }^{3}$, Mustafa K. ALTUNDAG ${ }^{4}$ \\ ${ }^{1}$ University of Recep Tayyip Erdogan, Faculty of Medicine, Department of Medical Oncology, Rize \\ ${ }^{2}$ University of Recep Tayyip Erdogan, Faculty of Medicine, Department of Endocrinology and Metabolism, Rize \\ ${ }^{3}$ Hacettepe University Cancer Institute, Basic Oncology, Ankara \\ ${ }^{4}$ Hacettepe University Cancer Institute, Department of Medical Oncology, Ankara, TURKEY
}

\begin{abstract}
Breast cancer is the most commonly diagnosed cancer in women, and obesity is a causative factor via estrogen exposure. Chemerin is a novel adipokine associated with obesity, metabolic syndrome, and polycystic ovary syndrome. We aimed to investigate serum chemerin levels in breast cancer and to correlate chemerin levels with clinicopathologic parameters of patients with newly diagnosed breast cancer. A total of 117 patients were enrolled the study. Serum chemerin levels were measured using an enzyme-linked immunosorbent assay. Ethical approval and informed consents were attained. Thirty-seven of the study population was metastatic and 80 were non-metastatic at the time of diagnosis. The mean chemerin levels were $257.3 \pm 68.7 \mathrm{ng} / \mathrm{mL}$ (148.1-526.0 ng/mL). Serum chemerin levels were significantly higher in post-menopausal women and patients with diabetes, hypertension, body mass index $(\mathrm{BMI}) \geq 30 \mathrm{~kg} / \mathrm{m}^{2}$ and age $\geq 50$ years. Chemerin levels were not different in either group $(\mathrm{p}=0.435)$. Multivariate analyses of parameters showed that CA15.3 and CEA levels were associated with metastatic disease. Our results propose that serum chemerin levels are not associated with breast cancer stage. However, further studies need to evaluate its role in carcinogenesis.
\end{abstract}

Keywords: Breast cancer, Chemerin, Body mass index.

ÖZET

\section{Meme Kanserinde Serum Chemerin Düzeyi}

Meme kanseri kadınlarda en sık görülen kanserdir. Obezite, östrojen fazlalı̆ı̆ı nedeniyle meme kanserinin etiyolojik faktörleri arasında yer almaktadır. Chemerin; obezite, metabolik sendrom ve polikistik over ile ilişkilendirilmiş yeni bir adipokin olarak bilinmektedir. Bu çalışmada meme kanserinde serum chemerin düzeyini ve yeni tanı hastalarda serum chemerin düzeyinin klinik ve patolojik parametreler ile korelasyonunu araştırdık. Çalışmaya toplam 117 bayan hasta alındı. Serum chemerin düzeyi enzyme-linked immunosorbent assay (ELISA) metodu ile ölçüldü. Etik kurul onayı alındı. Çalışmaya alınan hastalardan onam formu alındı. Çalışmaya alınan yeni tanı almış meme kanserli hastalardan 37'si metastatik iken, kalan 80 hasta ise metastatik değildi. Ortalama serum chemerin düzeyi 257.3 $\pm 68.7 \mathrm{ng} / \mathrm{mL}$ (148.1-526.0 ng/mL) olarak bulundu. Serum chemerin düzeyi post-menapozal kadınlarda, diyabeti ve hipertansiyonu olanlarda, vücut kitle indeksi(VKI) $\geq 30 \mathrm{~kg} / \mathrm{m}^{2}$ ve yaş $\geq 50$ olan hastalarda istatistik olarak anlamlı oranda daha yüksek bulundu. Hastalar metastatik ve metastatik olmayan diye gruplandıııldığında serum CA15.3 düzeyi dışında diğer parametrelerde anlamlı fark gözlenmedi. Serum chemerin düzeyleri her iki grupta benzerdi $(p=0.435)$. Çok değişkenli analizlerde serum CA15.3 ve CEA düzeyleri metastatik hastalık ile ilişkili bulundu. Çalışmamızda serum chemerin düzeyinin meme kanseri evresi ile ilişkili olmadığını bulduk. Meme kanseri etiyopatogenezinde chemerinin rolü olduğunu anlamak için kontrol grubu içeren geniş kapsamlı çalışmalara intiyaç vardır.

Anahtar Kelimeler: Meme kanseri, Chemerin, Vücut kitle indeksi 


\section{INTRODUCTION}

Breast cancer is the most common cancer in women, affecting 1 in 8 women during their lives. Extended estrogen exposure is one of the most important risk factors for breast cancer. Post-menopausal obesity, which is also an estrogen excess condition, increases the risk of breast cancer by more than 63\%. ${ }^{1}$ Moreover, overweight women have higher blood insulin levels and increased insulin activation of tyrosine kinase growth receptor pathways. ${ }^{2}$ Thus, it is another causative factor for breast cancer in obese women.

Chemerin is a recently identified adipokine that regulates adipogenesis and is associated with obesity, metabolic syndrome, and polycystic ovary syndrome. Many obesity-related parameters such as BMI, blood pressure, and insulin levels have been correlated with chemerin. ${ }^{3}$ Besides its autocrine effects, chemerin is related to inflammation via its paracrine effect. Tumor necrosis factor-alpha (TNF- $\alpha$ ) triggers the production of chemerin from adipocytes. ${ }^{4}$ Chemerin is a chemoattractant protein that acts as a ligand for the G protein-coupled receptor CMKLR 1. ${ }^{5}$ This receptor, also called ChemR23, is the major receptor for chemerin and mainly expressed in adipocytes and immune cells, additionally in breast tissue. ${ }^{6}$ The association of chemerin and cancer is not yet fully understood. Chemerin has been shown to have a potential role in immunoreactivity by acting as chemotactic for antigen presenting cells in inflammatory tissue. ${ }^{6}$ Thus, researchers may hypothesize that chemerin could have an antitumor role. Otherwise, chemerin also promotes angiogenesis via inducing matrix metalloproteinase secretion and activity. ${ }^{7}$ Therefore, it is thought that high levels of chemerin may have an initiating role in a further process; carcinogenesis, then metastasis.

Chemerin has been detected in breast cancer tissues. ${ }^{8}$ Chemerin expressions of tumor tissues were assessed in many studies. Serum chemerin levels were also investigated in a few studies in such cancers, gastric and colon cancer. The aim of our study was to investigate serum chemerin levels in breast cancer and to correlate chemerin levels with clinicopathologic parameters of patients with newly diagnosed breast cancer.

\section{PATIENTS AND METHODS}

\section{Patients and Methods}

One hundred seventeen female patients with newly diagnosed breast cancer were evaluated in a crosssectional observational study. All subjects were evaluated using a standardized form that included medical history and physical examination findings. Weight and height were measured. The patients' BMI (weight (kilograms)/height (meters) ${ }^{2}$ ) was calculated. Basal blood samples of subjects were tested for fasting glucose, hemoglobin A1C (HbA1c), total cholesterol (TC), high-density lipoprotein cholesterol (HDL-C), low-density lipoprotein cholesterol (LDL-C) and triglycerides (TG). Glucose was measured using a spectrophotometer assay (Human Gesellschaft, Wiesbaden, Germany), HbA1c was assessed using high-pressure liquid chromatography with a Primus CLC330 Ghb analyzer (Prismus, Kansas City, MO). Triglyceride, total and HDL cholesterol were measured using an enzymatic calorimetric test (Roche Diagnostics GmbH, Mannheim, Germany). LDL cholesterol was calculated using the Friedewald formula. Chemerin level measurement was performed according to the manufacturer's protocol (Biovendor Human Chemerin ELISA Kit). Research ethics committee approval was obtained from Hacettepe University Ethics Board and Commissions. Written informed consent was obtained from all participants.

\section{Statistical Analysis}

The statistical analyses were performed using SPSS version 18.0 (SPSS Inc., Chicago, IL, USA). Data on normal distribution are expressed as mean \pm SD and were compared using a t- test. Categorical variables are expressed as percentage and were compared using the Chi-square test or Fisher's exact test, as appropriate. Non-parametric variables were analyzed using the Mann-Whitney $\mathrm{U}$ test. Correlation analyses were performed using Spearman's and Pearson correlation tests. For the multivariate analysis, the possible factors(serum chemerin level, age at diagnosis, BMI, CEA and CA15-3) identified with univariate analyses were further entered into the logistic regression model to determine independent predictors of metastatic 
Table 1. Clinical characteristics of the patients

\begin{tabular}{|c|c|}
\hline Variables $(n=117)$ & \\
\hline Age at diagnosis (mean $\pm S D$ ) & $51.9 \pm 12.2$ \\
\hline Body mass index (kg/m²) & $28.7 \pm 5.1$ \\
\hline Menopause [n, (\%)] & \\
\hline Premenopausal & $56(47.9)$ \\
\hline Postmenopausal & $61(52.1)$ \\
\hline Histopathology [n, (\%)] & \\
\hline Invasive ductal carcinoma & 83 (70.9) \\
\hline Invasive lobular carcinoma & $8(6.8)$ \\
\hline Others ${ }^{\star}$ & $26(22.2)$ \\
\hline Estrogen receptor [n, (\%)] & \\
\hline Positive & $92(78.6)$ \\
\hline Negative & $25(21.4)$ \\
\hline Progesterone receptor [n, (\%)] & \\
\hline Positive & $81(69.2)$ \\
\hline Negative & $36(30.8)$ \\
\hline Her2 status [n, (\%)] & \\
\hline Positive & $36(30.8)$ \\
\hline Negative & $81(69.2)$ \\
\hline Stage $[n,(\%)]$ & \\
\hline Metastatic & 37 (31.6) \\
\hline Non-metastatic & $80(68.4)$ \\
\hline Chemerin (ng/mL) & $257.3 \pm 68.7$ \\
\hline
\end{tabular}

* The remaining 26 patients had rare histological types of breast cancer: 19 mixed ductal-lobular carcinoma, 2 neuroendocrine carcinoma, 2 mucinous carcinoma, 1 cribriform carcinoma, 1 metaplastic carcinoma and 1 tubular carcinoma. disease. In the statistical analyses, $\mathrm{p}<0.05$ value was considered significant.

\section{RESULTS}

The study population included 117 female patients with newly diagnosed breast cancer. Thirty-seven of which were metastatic and 80 were non-metastatic at the time of diagnosis. The mean age at diagnosis was $51.9 \pm 12.2$ years (range, $27-84$ years). The mean chemerin levels were $257.3 \pm 68.7 \mathrm{ng} /$ $\mathrm{mL}$ (range, $148.1-526.0 \mathrm{ng} / \mathrm{mL}$ ). Table 1 lists the demographic characteristics of the study population.

Serum chemerin levels were significantly higher in patients with diabetes. Similarly, serum chemerin levels were significantly higher in patients with older age, BMI $\geq 30 \mathrm{~kg} / \mathrm{m}^{2}$, hypertension, and in post-menopausal women (Figure 1). Serum chemerin levels were positively correlated with age at diagnosis, BMI, presence of diabetes mellitus, presence of hypertension, and post-menopausal status $(\mathrm{r}=0.26, \mathrm{p}=0.005 ; \mathrm{r}=0.30, \mathrm{p}=0.001$; $\mathrm{r}=0.26, \mathrm{p}=0.005 ; \mathrm{r}=0.317, \mathrm{p}<0.001$ and $\mathrm{r}=0.21$, $\mathrm{p}=0.018$, respectively). We also examined the as-
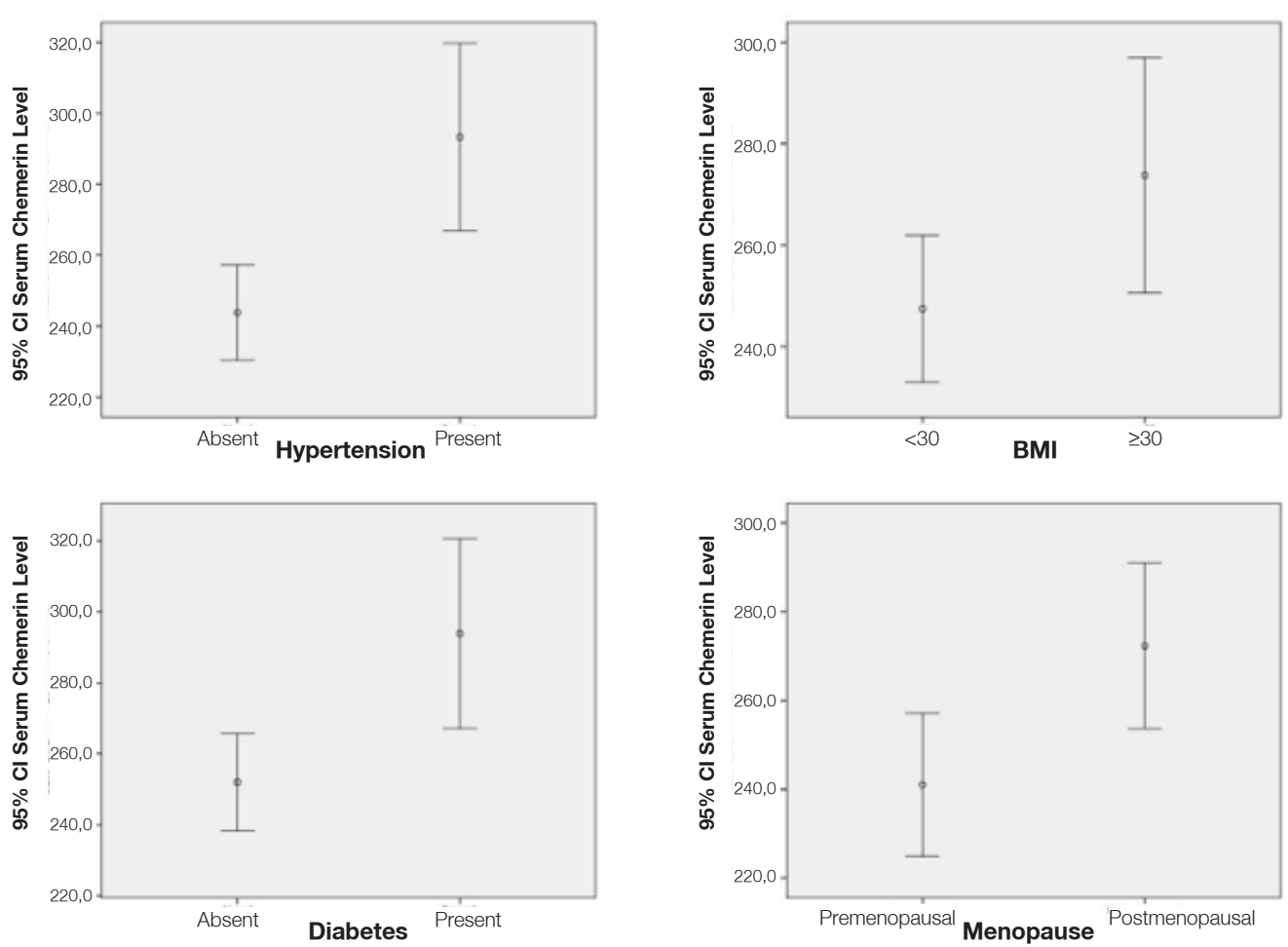

Figure 1. Serum Chemerin Levels in Different Clinical Parameters. Significant differences were observed in hypertensive, diabetic, obese and postmenopausal patients compared with normotensive, non-diabetic, normal weight and premenopausal patients $(p<$ $0.001, p=0.027, p=0.025, p=0.013$, respectively). $B M l=$ body mass index 
Table 2. Clinical and laboratory variables according to the metastatic status

\begin{tabular}{|llll|}
\hline & Metastatic disease & $\begin{array}{l}\text { Non-metastatic } \\
\text { disease }\end{array}$ & p \\
\hline No. of patients & 37 & 80 & 0.824 \\
Age, year & $52.3 \pm 11.8$ & $51.7 \pm 12.5$ & 0.682 \\
BMl, kg/m & $29.1 \pm 5.5$ & $28.6 \pm 4.9$ & 0.265 \\
Fasting plasma glucose, mg/dL & $104.4 \pm 47.1$ & $95.4 \pm 16.3$ & 0.508 \\
HbA1c, \% & $5.6 \pm 1.07$ & $5.5 \pm 0.7$ & 0.236 \\
CEA (U/mL) & $0.8-3401(2.5)$ & $0.6-5.6(1.3)$ & 0.017 \\
CA15.3 (U/mL) & $4.7-719.0(22.7)$ & $3.6-54.2(12.1)$ & 0.658 \\
Presence of diabetes [n, (\%)] & $4(10.8)$ & $11(13.8)$ & 0.164 \\
Presence of hypertension [n, (\%)] & $7(18.9)$ & $25(31.3)$ & 0.281 \\
Menopause [n, (\%)] & & & 0.310 \\
Premenopausal & $15(40.5)$ & $41(51.3)$ & 0.260 \\
Postmenopausal & $22(59.5)$ & $39(48.8)$ & 0.551 \\
Presence of estrogen receptor [n, (\%)] & $27(73.0)$ & $65(81.3)$ & $58(72.5)$ \\
Presence of progesterone receptor [n, (\%)] & $23(62.2)$ & $26(32.5)$ & \\
Presence of HER2 [n, (\%)] & $10(27.0)$ & & \\
\hline
\end{tabular}

Table 3. Multivariate analyses of the clinical and laboratory parameters associated with the presence of metastatic breast cancer

\begin{tabular}{|lll|}
\hline & $\mathbf{R R}(\mathbf{9 5} \mathbf{\%} \mathbf{C l})$ & $\mathbf{p}$ \\
\hline Chemerin & $0.99(0.99-1.00)$ & 0.832 \\
Age at diagnosis & $0.95(0.87-1.03)$ & 0.266 \\
BMI & $1.00(0.88-1.14)$ & 0.930 \\
CEA & $1.32(1.06-1.66)$ & 0.012 \\
CA15.3 & $1.08(1.03-1.14)$ & 0.004 \\
\hline
\end{tabular}

sociation of serum chemerin levels with fasting plasma glucose, HbA1c, LDL-cholesterol, HDLcholesterol, triglyceride, CA15.3 and CEA, but no association was observed.

Patients were divided into subgroups according to metastatic status: metastatic and non-metastatic disease. The results were as follows: in 37 women who had metastatic breast cancer and 80 women who had non-metastatic breast cancer, chemerin levels were $250.0 \pm 58.9 \mathrm{ng} / \mathrm{mL}$ and $260.7 \pm 72.9$ $\mathrm{ng} / \mathrm{mL}$, respectively. When clinical characteristics were compared according to the metastatic and non-metastatic disease, with the exception of serum CA15.3 levels, there were no significant differences in most parameters (Table 2). Chemerin levels were not different in either group $(\mathrm{p}=0.435)$. Multivariate analyses of parameters also showed that CA15.3 and CEA levels were associated with metastatic disease (Table 3).

\section{DISCUSSION}

To our knowledge, this study is the first study of chemerin in patients with breast cancer. In this study, we found that there was no difference in plasma chemerin levels between patients with metastatic and non-metastatic breast cancer. Similar to the literature, BMI and diabetes mellitus was found strongly correlated with chemerin levels. In addition, chemerin levels were affected by age of disease onset and menopausal status.

Several adipokines have been implied in cancer development, mainly through insulin resistance, inflammation, and production of sex hormones. An increased level of most of these adipokines such as leptin, resistin, apelin, and visfatin, has played a pro-carcinogenic role. ${ }^{9}$ On the other hand, some adipokines such as adiponectin are known to be anti-carcinogenic. Chemerin is a recently identified adipokine that regulates adipocyte development and metabolic functions, as well as immunity. ${ }^{10,11}$ There are conflicting data about the link between chemerin and cancer. This novel adipokine may have tumorigenic or anti-tumor effects. Chemerin may have an antitumor role via recruitment of natural killer (NK) cells. Thus, the immune system recognizes cancer cells and fights them in the event of high levels of chemerin. ${ }^{12}$ Down regulation of chemerin expression was revealed in non-small cell lung cancer, melanoma, hepatocellular carci- 
International Journal of Hematology and Oncology

noma, and squamous cell carcinoma of the skin. ${ }^{13-}$ ${ }^{16}$ On the other hand, in gastric cancer and oral squamous cell cancer of the tongue, high chemerin levels were associated with aggressive features such as advanced stage and increased tumor angiogenesis. ${ }^{17,18}$ Chemerin promotes angiogenesis by triggering the production and activity of matrix metalloproteinase, which plays a crucial role in angiogenesis. In this study, chemerin levels of patients with early or advanced-stage breast cancer were similar.

As with many adipokines, increased serum chemerin levels show a correlation with BMI, obesity, and metabolic syndrome through its local inflammatory response via chemokine-like receptor- $1 .{ }^{19}$ Moreover, other metabolic indices, for instance plasma triglyceride levels and systolic blood pressure, have been shown to be correlated with serum chemerin levels. ${ }^{20}$ Serum chemerin levels were found significantly different between individuals with normal glucose tolerance and individuals with type II diabetes and their first-degree relatives in a small study. ${ }^{21}$ In our study, chemerin levels were correlated with age of diagnosis, BMI, presence of diabetes mellitus, presence of hypertension, and post-menopausal status. These findings are consistent with the literature.

Limitations of our study include the lack of a control group without breast cancer. Controlled crosssectional studies necessitate examining whether chemerin is involved in the development of breast cancer. There are some factors that influence other adiponectin levels, such as diet and exercise. ${ }^{22}$ Therefore, measurement of serum chemerin may be altered by other factors. In some previous studies, chemerin expression was immunocytochemically investigated in tumor and non-tumor tissues. Serum chemerin levels and tissue chemerin expressions should be analyzed together. Another limitation of our study was the small number of patients.

In conclusion, we demonstrated that serum chemerin level is not associated with the stage of breast cancer Further studies with control groups should investigate the role of chemerin in the carcinogenesis and development of breast cancer in postmenopausal women.

\section{Acknowledgement:}

This study was funded by Turkish Society of Medical Oncology (Grant number P-TTOD-2015-27)

\section{REFERENCES}

1. Calle EE, Rodriguez C, Walker-Thurmond K, et al. Overweight, obesity, and mortality from cancer in a prospectively studied cohort of U.S. adults. New Eng J Med 348: 16251638, 2003.

2. Gunter MJ, Hoover DR, Yu H, et al. Insulin, insulin-like growth factor-I, and risk of breast cancer in postmenopausal women. J Natl Cancer Inst 101: 48-60, 2009.

3. Bozaoglu K, Bolton K, McMillan J, et al. Chemerin is a novel adipokine associated with obesity and metabolic syndrome. Endocrinology 148: 4687-4694, 2007.

4. Parlee SD, Ernst MC, Muruganandan S, et al. Serum chemerin levels vary with time of day and are modified by obesity and tumor necrosis factor-\{alpha\}. Endocrinology 151: 25902602, 2010.

5. Roh SG, Song SH, Choi KC, et al. Chemerin--a new adipokine that modulates adipogenesis via its own receptor. Biochem Biophys Res Commun 362: 1013-1018, 2007.

6. Wittamer V, Franssen JD, Vulcano M, et al. Specific recruitment of antigen-presenting cells by chemerin, a novel processed ligand from human inflammatory fluids. J Exp Med 198: 977-985, 2003.

7. Kaur J, Adya R, Tan BK, et al. Identification of chemerin receptor (ChemR23) in human endothelial cells: chemerin-induced endothelial angiogenesis. Biochem Biophys Res Commun 391: 1762-1768, 2010.

8. Sarmadi P, Tunali G, Esendagli-Yilmaz G, et al. CRAM-A indicates IFN-gamma-associated inflammatory response in breast cancer. Mol Immun 68(2 Pt C): 692-698, 2015.

9. Cabia B, Andrade S, Carreira MC, et al. A role for novel adipose tissue-secreted factors in obesity-related carcinogenesis. Obes Rev 17: 361-376, 2016.

10. Ernst MC, Sinal CJ. Chemerin: at the crossroads of inflammation and obesity. Trends Endocrinol Metab 21: 660-667, 2010.

11. Ernst MC, Issa M, Goralski KB, et al. Chemerin exacerbates glucose intolerance in mouse models of obesity and diabetes. Endocrinology 151: 1998-2007, 2010.

12. Parolini S, Santoro A, Marcenaro E, et al. The role of chemerin in the colocalization of NK and dendritic cell subsets into inflamed tissues. Blood 109: 3625-3632, 2007.

13. Zhao S. LC, Ye Y, Peng F, et al. Expression of chemerin correlates with a favorable prognosis in patients with non-small cell lung cancer. Lab Medicine 42: 553-557, 2011. 
International Journal of Hematology and Oncology

14. Pachynski RK, Zabel BA, Kohrt HE, et al. The chemoattractant chemerin suppresses melanoma by recruiting natural killer cell antitumor defenses. J Exp Med 209: 1427-3145, 2012.

15. Lin $\mathrm{W}$, Chen $\mathrm{YL}$, Jiang $\mathrm{L}$, et al. Reduced expression of chemerin is associated with a poor prognosis and a lowed infiltration of both dendritic cells and natural killer cells in human hepatocellular carcinoma. Clin Lab 57: 879-885, 2011.

16. Zheng Y, Luo S, Wang G, et al. Downregulation of tazarotene induced gene-2 (TIG2) in skin squamous cell carcinoma. Eur J Dermatol 18: 638-641, 2008.

17. Wang C, Wu WK, Liu X, et al. Increased serum chemerin level promotes cellular invasiveness in gastric cancer: a clinical and experimental study. Peptides 2014; 51: 131-8.

18. Wang N, Wang QJ, Feng $Y Y$, et al. Overexpression of chemerin was associated with tumor angiogenesis and poor clinical outcome in squamous cell carcinoma of the oral tongue. Clinical Oral Investig 18: 997-1004, 2014.

19. Gatalan V, Gomez-Ambrosi J, Rodriguez A, et al. Increased levels of chemerin and its receptor, chemokine-like receptor-1, in obesity are related to inflammation: tumor necrosis factor-alpha stimulates mRNA levels of chemerin in visceral adipocytes from obese patients. Surg Obes Relat Dis 9: 306314, 2013.

20. Li Y, Shi B, Li S. Association between serum chemerin concentrations and clinical indices in obesity or metabolic syndrome: a meta-analysis. PloS One 9: e113915, 2014.

21. Zhuang $\mathrm{XH}$, Sun FD, Chen $\mathrm{SH}$, et al. Circulating chemerin levels are increased in first-degree relatives of type 2 diabetic patients. Clin Lab 60: 983-988, 2014.

22. Fogteloo AJ, Pijl H, Roelfsema F, et al. Impact of meal timing and frequency on the twenty-four-hour leptin rhythm. Horm Res 62: 71-78, 2004.

\section{Correspondence:}

Dr. Serkan AKIN

Recep Tayyip Erdogan Universitesi Tip Fakültesi

Tibbi Onkoloji Anabilim Dali

53100, RIZE/ TURKEY

Tel: (+90-464) 2130491

Fax: (+90-464) 2170364

e-mail: drserkanakin@gmail.com 